\title{
The Mediating Role of Psychological Contract Fulfillment in the Relationship Between Organizational Support and Employee Performance
}

\author{
Samar Mahmoud Sheikh Elsouk ${ }^{1, *}$, Shawky Elsubbagh ${ }^{1}$, Baker Ayoun $^{2}$, Alaa Radwan $^{1}$ \\ ${ }^{1}$ Management Department, Faculty of Commerce, Menofia University, Menofia, Egypt \\ ${ }^{2}$ Department of Nutrition, Dietetics, and Hospitality Management, Auburn University, Auburn, Alabama, USA \\ Email address: \\ Samarm000@gmail.com (S. M. S. Elsouk), elsubbaugh@yahoo.com (S. Elsubbagh), bma0002@auburn.edu (B. Ayoun), \\ alaaradwan_70@yahoo.com (A. Radwan) \\ *Corresponding author
}

\section{To cite this article:}

Samar Mahmoud Sheikh Elsouk, Shawky Elsubbagh, Baker Ayoun, Alaa Radwan. The Mediating Role of Psychological Contract Fulfillment in the Relationship Between Organizational Support and Employee Performance. Psychology and Behavioral Sciences.

Vol. 10, No. 1, 2021, pp. 25-38. doi: 10.11648/j.pbs.20211001.14

Received: November 3, 2020; Accepted: November 23, 2020; Published: January 25, 2021

\begin{abstract}
Increased competition, technologies, and downsizing, demographic diversity affect employment relationships and make the academic organization becoming more complex. As competition between firms becomes more fierce and fierce, the state of talent turnover directly affects the survival and development of the company. The human resource department is committed to effectively improving employees' enthusiasm and giving full play to employees' ability to tap into employees' potential, and then improve employee performance. One of the indicators of the company's success is the performance of the employees who work efficiently and effectively that would produce a good performance. Depending on the social exchange theory. This study examines the positive role of psychological contract fulfillment in the linking mechanism between organizational support and employee performance. The fact that organizational support plays an important role in enhancing employee performance has been studied in the literature. However, studying the mediating role of psychological contract fulfillment in the relationship between organizational support and employee performance is still needed. It is argued that psychological contract fulfillment is a vital mediator in the relationship between organizational support and employee performance. Therefore, the major aim of the current study is to provide empirical support for the relationship between organizational support and job performance and psychological contract fulfillment as a mediator.
\end{abstract}

Keywords: Organizational Support, Psychological Contract, Employee Performance

\section{Introduction}

All organizations and universities, in particular, striving for progress and prosperity. Human resources are considered the main factor for organizational excellence and development, therefore, Management of organizations, practitioners of organizational behavior and human resource management at present in particular are in a struggle to find out the causes of employee low performance. To perform better, there is a need to emphasize the physical and psychological health of the employees [4].

The psychological contract concept drew the attention and interest of academics and professionals over the past few decades [5]. A Psychological Contract (PC) plays an important role in how employees perceive their institutions as well as how they will perform [6]. A psychological contract is a set of existing unwritten expectations between employees and their employers. A Psychological contract is a system of beliefs that encompasses the actions employees believe are expected of them and what response they expect in return from their employer, and, reciprocally, the actions employers believe are expected of them and what response they expect in return from their employees [7]. Perceived organizational support (POS) has been viewed as an important factor in the employee-organization relationship that influences stress, well-being, and employee Performance [8]. 
Perceived organizational support is the perception employees have concerning whether the organization values their contributions and cares about their well-being. Perceived organizational support also fulfills socioemotional needs, resulting in greater identification and commitment to the organization, an increased desire to help the organization succeed, and greater psychological well-being [9]. PC and POS are both rooted in the social exchange framework. While PC is a way of representing the employment relationship in the mind of the employee, POS refers to an employee's belief that the employer values his/her contribution and demonstrates concern for his/her well-being at work. Consistent with the rule of reciprocity norms applied to the work context, in exchange for the fulfillment of obligations and promises by their employer and through POS, employees are more committed, more satisfied, less prone to leave, and more willing to make extra efforts that go beyond the job duties [10]. Employees who perceive high organizational support concentrate more on the social exchange between themselves and organizations [11].

None of the relationships will prosper in the growing human economy before and unless they have the correct awareness and ability to reinforce the bond of their interactions. It is simply an individual view of looking at the bonding of the partnership to further strengthen or dissolve it. Of individual worker has evolved to be regarded as an asset to the educational institutions, and the psychological wellbeing of the employer plays an important role in the use of an organization's assets. However, although there are ample studies available on perceived organizational support, psychological contract, and employee performance, the study of the role of psychological contract fulfillment as a mediator between organizational support and employee performance remains needed. This study will investigate the role of organizational support in psychological contract fulfillment to improve employee performance.

The current study makes twofold contributions. First, we offer a theoretical rationale for and provide an empirical test of the organizational support as an additional explanation for effects of psychological contract fulfillment on employee outcomes to better understand how employees respond to the psychological contract fulfillment. Second, this study examines the mediating role of psychological contract fulfillment between both the perceived organizational support and employee performance. This examination is crucial because it helps to provide a test of the connections between organizational support and employee performance theories in general and in the educational institutional in particular.

\section{Theoretical Background and Hypothesis Development}

\subsection{Organizational Support}

The perceived organizational support construct was developed in 1986 by Robert Eisenberger [12]. Perceived organized support is theoretically based on social exchange theory [13]. Blau (1964) was among the first to differentiate social exchange from the economic exchange. Blau suggested that social exchange, unlike economic exchange, refers to relationships that involve unspecified future obligations. Also, the social exchange does not occur on a calculated basis. Economic exchange is based on transactions, but the key to social exchange relationships is the individuals' trust in the other parties to fairly discharge their obligations in the long run [14]. According to social exchange theory (Blau, 1964; Gouldner, 1960), employees who perceive that they are supported by their organization tend to value it more and actively collaborate to achieve its goals [13].

The social exchange has been conceptualized in two ways in the management and organizational literature. The first conceptualization characterizes social exchange as a global exchange relationship between employees and the organization. This characterization focuses on the employee's belief that the organization values his/her efforts and contributions to the organization and cares about their wellbeing which is termed perceived organizational support. The second conceptualization of social exchange focuses more on the dyadic relationship between employee and supervisor. From this perspective, the employee perceives his/her direct supervisor or manager cares about their wellbeing and values their contribution back to the organization. This conceptualization can be termed perceived supervisor support [12].

The theory of organizational support draws on the social exchange theory to demonstrate the relationship between employees and the organization [13]. This relationship significantly influences the increase of the positive orientation and well-being of the employees [15]. Organizational Support Theory suggested that employees will feel obligated to return the favor upon receiving favorable treatment from supervisors or the organization. Such a felt obligation represents employees' positive orientation toward the organization [16].

Perceived organizational support was positively related to social exchange and negatively related to economic exchange [9]. Perceived organizational support is based on employees' attitudes concerning the value the organization places on their contribution and the degree to which the organization is believed to attend to their well-being. This construct aligns with the idea that employees have a high need for esteem surrounding their work, for approval from colleagues and supervisors who they deem important and social affiliation with others. This theory of perceived organizational support explains that employees form a perception of the organization and how it values their contributions and cares for their well-being. This perception corresponds to one's sense of the benefits of increased work [17].

Eisenberger et al. defined perceived organizational support as "global beliefs developed by employees concerning the extent to which the organization values their contributions and cares about their well-being [13]. Perceived Organizational Support (POS) is the perception of employees about the support they receive from the organization. POS 
stands for the employee's belief about the availability of help from the organization when it is needed to perform the job effectively and overcome difficult conditions [18].

The organizational support theory suggests that employees pay attention to how organizations treat them to discern the extent to which the organization is supportive and values their contributions. Employees associate the treatment offered to them by agents of the organization as indicative of the organization's overall favorable or unfavorable orientation towards them [19].

Perceived organizational support is related to motivation is based on the idea that perceived organizational support would increase the satisfaction of psychological needs. As it is operationalized as caring about employees, perceived organizational support is likely to make employees feel more highly related to the organization and its members; as it is described as trusting employees, it is likely to make employees feel more autonomous in their job; and as it is also described as providing employees with the resources necessary to perform one's job efficiently, it is likely to make employees feel more competent [20].

Perceived organizational support makes employees feel more related to the organization [21], it is likely to make them feel more autonomous at work. Perceived organizational support can also provide employees with the resources necessary to perform their job more efficiently and make them feel more competent and motivated [13].

Employees who have high perceptions of organizational support will have more positive feelings about their organizations [15].

Further, perceived organizational support has been activated into four dimensions: fairness, job condition, supervisory support, and organizational reward [22]. As perceived organizational support increases when employees believe they receive favorable treatment from the organization in terms of supervisory support, fairness and procedural justice, and rewards and job conditions [23].

The Perceived organizational support composited by threedimensional mental structure is widely accepted, which includes the organizational identification of employee's value, organizational care of employee's benefit, and organizational support of employee's work [24].

Perceived Organizational Support Scale which is developed by Derinbay, made up of 29 items and 3 dimensions educational support, administrative support, justice [25].

Eisenberger, Huntington, Hutchison, and Sowa (1986) suggested that POS is influenced by a variety of factors, such as organizational rewards in the form of praise, money, promotions, and influence, all given by the organization to employees as a way of communicating to employees that they are valued [20]. There are several antecedents of POS, including" (1) perceptions of the organization, such as justice and politics, (2) job conditions, (3) supervisor support, (4) personality, and (5) human resource (HR) practices [26]. Perceived organizational support can classified in to financial POS, career POS, and adjustment POS [27].
Most prior research has examined the relation of POS on individuals' work attitudes and behaviors. Perceived Organizational Support has been proven to be related to a variety of work-related attitudes and outcomes [19]. For example, research has found that POS is positively related to job satisfaction [28], affective commitment [29], organizational citizenship behavior and task performance [30], employees' job performance [31], well-being and learning self-efficacy [32], organizational trust [25], safety management performance [24], job embeddedness [33].

Not only is POS a strong predictor of positive work behavior, but it is also a strong predictor of employees' active negative work behaviors [14]. For instance, [15] study found a negative and significant relationship between teacher views on organizational support and psychological contract violation. The study confirmed a strong practically significant negative relationship between Perceived Organizational Support and the employee's Intention to Quit [19], turn over intention [33].

Besides, POS plays an important role as a moderator, for example, the [34] study showed that POS decreases the negative effect of narcissism on work satisfaction and colleague satisfaction among the sub-factors of job satisfaction and affective commitment among the sub-factors of organizational commitment. Also, organizational support was found to moderate the indirect effect of employees' CSR perceptions and job performance through job crafting [35]. Perceived organizational support as a moderator of the relationship between the Dark Triad personality traits of narcissism, Machiavellianism, and psychopathy with specific types of counterproductive work behavior [36]. Organizational support moderates the relationship between job insecurity and feedback-seeking behavior [11].

\subsection{Psychological Contract}

Employees are the main key to sustainable competitive advantage, and it follows that relationships between employers and employees are critical to ensuring productivity and the continued release of innovation and creativity [37]. Psychological contract theory is an important theory for studying the employment relationship [38].

The majority of research on psychological contract theory has been carried out on the dyad between the employer and the employee, and the reciprocal expectations and obligations they perceive [5].

The exploration of the concept of psychological contract mainly experienced the emergence stage (from the early 1960 s to the late 1980s) and the development stage (from the late 1980 s to the present) according to the previous study [38].

The term of the psychological contract was introduced by Argyris (1960). Argyris utilized psychological contract to demonstrate the relationship between supervisors and employees in his famous work Understanding organizational behavior. For Argyris, the psychological contract captured the unwritten rules and expectations that were held by employees and employers in respect of each other [37]. A psychological 
contract can be understood as an understanding of mutual responsibilities and obligations between employees and enterprises. This kind of understanding doesn't have a written document, but it performs on the unspoken subjective commitment of staff and enterprise [1]. The psychological contract embraces perceptions and beliefs on an array of items that were promised, mentioned, or in some way perceived but not written on the formal written legal contract [39]. Unlike contracts on paper where two parties reach an agreement, a psychological contract is one person's belief regarding the reciprocal relationship, which is perceptual, unwritten, and implicit. Since no contract can be perfectly complete. There is a psychological component in all contracts, where a party to the agreement will assume certain obligations from the other party and vice versa [40]. Individuals' beliefs that link the fulfillment of their own specific obligations to their receipt of rewards are the basis of psychological contracts [41].

What differentiates an actual employment contract from a psychological contract is that the psychological contract is based on expected, and not necessarily required, employer inducements, and reciprocal employee obligations [42].

Psychological contracts are much broader than economic and legal contracts [43]. A psychological contract can exist in both the presence and the absence of economic contracts [44]. Unlike economic contracts, psychological contracts are not formal; rather they represent a mental model or schema of conceptually related elements gleaned from the employee's experiences with the organization, such as interviews, written documents, and organizational practices [44]. Three important dimensions of the PC distinguish it from other forms of social and implied contracts: mutuality, psychological, and individuality [45].

The psychological contract is grounded in processes such as first, pre-employment negotiation, which is the foundation of the psychological contract. Second, redefining a psychological contract, ensuring that there is a clear line of communication between the employee and employer regarding expectations; and third, a fair, balanced, and dynamic relationship which does not lead to a psychological contract breach by the employer [46].

The psychological contract is utilized as one of the important tools to resolve many Human Resource (HR) related issues [5]. It is essential to understanding the attitudes and behaviors of employees in their organizations [47]. The key function of psychological contracts lies in their capacity to reduce insecurities and help both employees and organizations meet their needs [48].

Psychological contracts are favorable conditions perceived by employees during employment, built on promises, statements, or even attitudes made by management [39]. Psychological contracts are mental models or schemas that govern how employees understand their exchange relationships with their employers [44]. Psychological contract is the employment relationship between an organization and an individual employee concerning the obligations that each party has to the other. In the early days, it was defined as beliefs about what employees are entitled to receive from their employer [49].

Social exchanges entail unspecified obligations, while the obligations in economic exchanges are more commonly tangible. Social exchange relationships create priceless and long-lasting social patterns. Therefore, according to this theory, employees' values determine the relationship outcomes with peers and employers. Scholars developed these concepts and placed the social and economic exchanges in the context of the psychological contract, labeling them as transactional and relational contracts [39].

Mac Neil 1985 was the first to classify the dimensions of the psychological contract between employees and organization from a theoretical Perspective in two types of transactional contracts and relational contracts [38].

These two types do not refer to the specific obligations that are exchanged between employees and organizations, but more broadly to the type of relationship that evolves between an employee and the employer [47]. Relational and transactional types of psychological contracts are relative rather than mutually Exclusive [50].

Transactional psychological contracts: are characterized by an economic focus; they lead to short-term employment relationships in which performance requirements and mutual obligations are specified [51]. Transactional contracts are based on extrinsic factors and focus on tangible, mainly monetary factors, for a specific period-they are explicit, stagnant, and narrow in scope [39]. Transactional contracts are specific and quid pro quo in nature, primarily depending on employees' input to the organization [48].

Relational psychological contracts: lead to long-term employment relationships in which mutual obligations are less specified and in which exchanges are based on socioemotional resources [51]. Focused on intrinsic factors such as status and recognition, the potential for creativity, employment security, work-life balance, healthy work ethics, and career advancement - they are based on indefiniteness, dynamism, and expanded objectives [39]. Relational contracts serve to maintain the employee-employer relationship and are not fundamentally quid pro quo [48].

While it is straightforward to make a distinction between employees on short-term contracts, likely to have a transactional contract, and employees on permanent contracts, more likely to have a relational contract, this distinction is less clear-cut in reality [47]. When employees feel they have not received the benefits from their organization that they expected to receive, this is referred to as a PC breach [52]. The concept of psychological contract breach has become increasingly relevant with the growing pace of globalization and the continuous economic cycles leading to inevitable restructuring exercises and loss of jobs [39].

There is a difference between a psychological contract breach and a psychological contract violation, while the breach is only assimilated to the awareness that an obligation has not been honored by the employer, violations frame the emotional reactions from this awareness that tends to be generated from perceived breaches [39]. Psychological 
contract breach leads to feelings of violation and can occur even when employees' economic contracts are fulfilled [44].

Psychological contracts have generated considerable interest from organizational scholars and practitioners for the past several decades, largely due to the negative organizational outcomes that arise when these contracts are violated [42].

Parzefall and Coyle-Shapiro (2011) classify the events that lead to the breach of contract into four categories, namely breach of a specific obligation, chains of breaches, secondary breaches, and everyday Breaches [39]. Organizations can potentially reduce psychological contract breaches by implementing more formalized and internally consistent human resource practices. HRM practices are the primary means through which organizations communicate the expectations that create employees' psychological contracts [41].

Most prior research has examined the relation of psychological contract on individuals' work attitudes and behaviors. For example, research has found that $\mathrm{PC}$ is positively related to promotive voice behavior [53], job performance $[1,3]$, as well as with perceived organizational support and organizational citizenship behavior [54], working Generation Y's perceived fairness of performance appraisal [55], internal branding [56], organizational citizenship behavior [5].

Psychological contract breach is negatively related to organizational identification and affective commitment [57], job satisfaction [48], trust [39], positively related to frustration and employee dysfunctional behavior [58], intention to leave the job [39]. Psychological contract breach as a mediator between work-home interference and job satisfaction [48], partially mediates the relation between budgeting type and budgetary misreporting [44].

\subsection{Employee Performance}

The success of any organization to achieve its organizational strategies and goals depend heavily on the performance of the employees [59].

Enhancing the employee performance considered the main aim for any organization as a result of increasing competition between organizations [11] and it presents the actions and behaviors that related to organizational goals [60]. Organizations take care of their employees and value their works as they are the foundation for its survival [61]. Employee performance is considered an important activity for human resource management [62]. It's a key factor for improving organization performance [31].

Many researchers saw employee performance as a multidimension concept [63]. Job performance is the degree to which employees meeting the duties specified in their job description [64]. Employee performance is a function of ability and motivation, where ability is comprised of the skills, training, and resources required for performing a task, and motivation is described as an inner force that drives an individual to act towards something [59]. Job performance may be conceptualized as acts and behaviors individual basis that contribute to acquiring the jobs and organizational goals. Employees struggle to consume their energy or stamina for achieving the organizational goals, consequently the employee receives remuneration from the organization. If an employee feels insecure, consequently his performance decreases with time [65].

Gilbert (1978) is commonly described as the father of performance technology; as an engineer, he applied his understanding of the process of technological improvement to human beings. He argued that the absence of performance support, not a person's lack of knowledge or skill, was the greatest barrier to idealistic or worthy performance. He further identified six variables necessary to improve human performance: information, resources, incentives, knowledge, capacity, and motives [66].

Although different scholars have indicated different dimensions of employee performance, most of the dimensions can be classified into two main aspects: in-role performance and extra-role performance. In-role performance is related to performance that is specified in the employee's job description and is recognized by the company's formal reward system [67]. In-role performance focus on how well an employee work in his/her works [68].

Extra role performance is related to the employee's behaviors that benefit the organization and are not specified in the employee's job description or the company's formal reward system [67]. Extra role performance focus on how good an employee is willing to do anything beyond his/her work. An employee with high extra-role performance used to be willing to help his/her workmates and spend extra hours finishing his/her work even if without any demand from the supervisor [68]. Two methods can be used to measure the performance of an employee the first is the supervisor assessment and the second is the self-assessment and this last method is the practical way to measure the performance [68].

Most of the previous research examined the relation of employee performance on individuals' work attitudes and behaviors. For example, research has found that employee performance is positively related to effective communication [66], work engagement [69], job crafting [70], and, selfefficacy [71] and negatively related with stress [72].

To conclude the above-mentioned, this study advances previous research by examining the ongoing reciprocal relation-ship between employees' perceptions of organizational support and employee performance and also explores whether psychological contract fulfillment moderate these relationships. As this study aims to a better understanding of the mechanisms by which employee performance is influenced by psychological contract fulfillment and the role of organizational support in psychological contract fulfillment. In other words, examine the mediating role of the psychological contract in the relationship between organizational support and employee performance. Based on current organizational support, psychological contract, and employee performance research. Hence, the following hypotheses formulated in figure 1: 


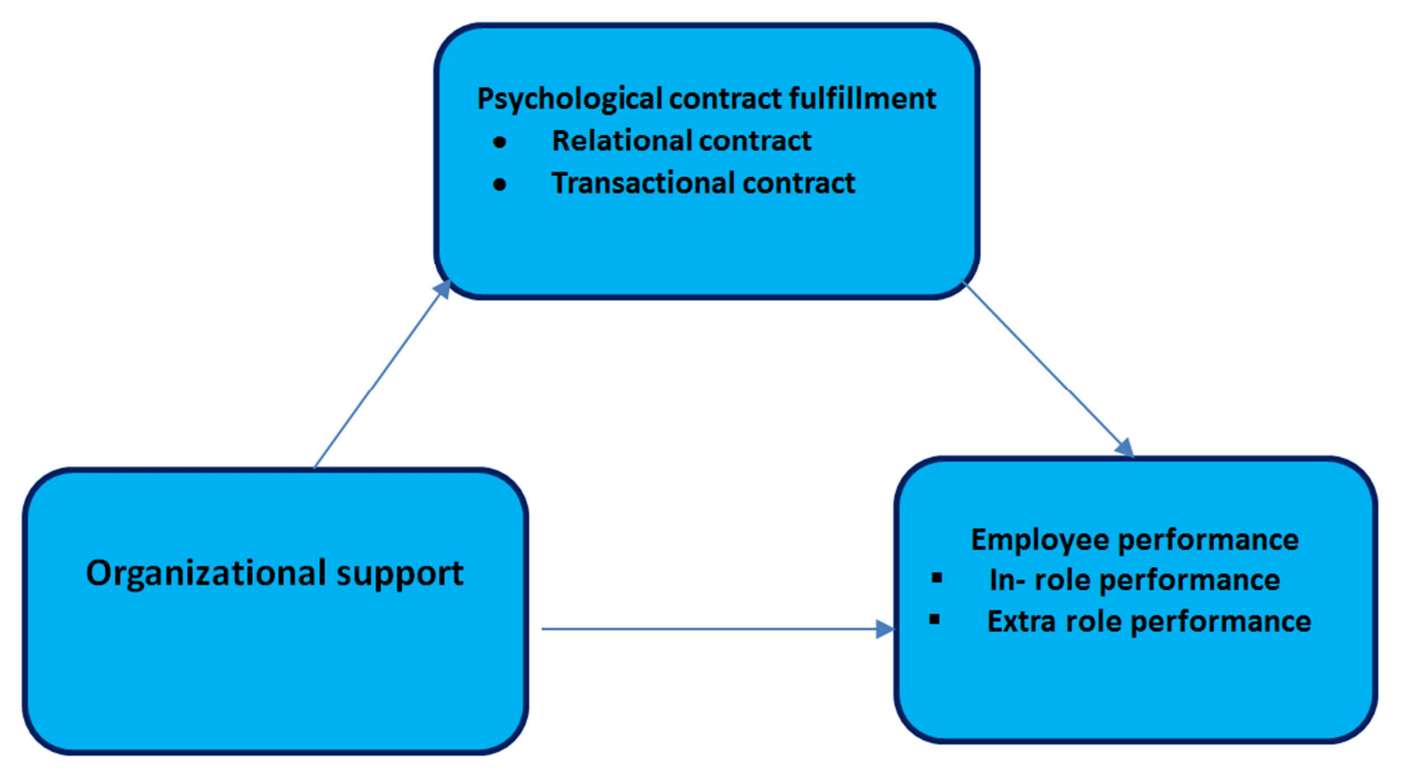

Figure 1. Proposed model for the study.

We are responding to calls to integrate social exchange theory and psychological contracts by examining how the quality of the social exchange relationship modifies the reciprocity between employer and employee. Perceived organizational support capturing the quality of an individual's exchange with their organization. Perceived Organizational support and psychological contract are similar in that they refer to a set of items that are exchanged as part of the business relationship [73] however, they are clearly distinct conceptually psychological contract is the unspoken and informal understanding that an employee will contribute certain things to the organization (for example, capacity to work and position of will) and will receive certain things in return (for example, reasonable salaries and benefits)[74]. In line with previous studies $[75,76]$. We supposed that organizational support have positive effect on psychological contract fulfillment.

H1: There is statistically significant relationship between organizational support and psychological contract fulfillment by its dimension (contract of relations, contract of transactions) among employees in the university under study.

Under the psychological contract, the employee may believe that if he works hard and obtains favorable performance reviews, he will receive an annual bonus, periodic increases and promotions, and will not be laid off [74]. Evidence supports employees maintain balance by matching their contributions with what they perceive in this psychological contract, this contract is associated with a wide range of employees' behaviors. Such as job stress [77], employee performance [73], citizenship behavior [78].

Performance at the individual level depends on the things you need to do in your job, or performance on the job, and things that add value but are not part of the formal job description. These "add-ons" are called extras or organizational citizenship behaviors (OCBs). At this point, it may be easier to consider role performance as having both productivity and quality dimensions associated with certain standards that you must meet in order to do your job. In contrast, OCBs can be understood as individual behaviors beneficial to the organization which are discretionary, and they are not recognized directly or explicitly by the official bodies [74]. Based on the above arguments, employees are expected to increase the level at which they perform their duties when they believe that the promises made to them have been fulfilled in line with predictions from social exchange theory and the norm of reciprocity.

$\mathrm{H} 2$ : The higher fulfillment of psychological contract the better performance of employees in the university under study.

Psychological contract plays vital role as a mediator between organizational variables. The studies will employ social exchange theory in agreement with organizational researchers who have supported this theory in explaining and confirming the mediating mechanism. Relationships. Such as paternalistic leadership and turnover intention [79], human resources management practices and job outcomes [3]. Ethical leadership and employee extra performance [80].

Based on this discussion, the study proposes that psychological contract fulfillment mediated the relationship between organizational support and employee performance.

H3: Psychological contract fulfillment mediates the relationship between organizational support and the performance of the employee.

So that the organizational support will affect the psychological contract fulfillment and psychological contract fulfillment will affect the performance of the employee. Since a psychological contract relies on individual expectations and interpretations of what has been undertaken through the employment contract, this means that employees will differ in their views on the contract. From an individual perspective, factors that shape psychological contracts 
include gender, age, education; job, work experience, and personal life. Likewise, there are some demographic variables (age, work experience) had correlation (negative correlation) and other (gender) had no correlation with organizational support [54].

In addition, various demographic variables such as gender, age, education, and organizational tenure were examined as precedents for performance [81].

Demographic variables are expected to affect the perceived organizational support, fulfillment of psychological contract, and employee performance. Based on these discussions.

H4: There is statistically significant relationship between Demographic variables and organizational support, psychological contract, and employee performance separately.

\section{Methods}

\subsection{Measurement}

A quantitative approach was used in the research. An online self-administered survey in addition to an in-person survey was used to collect data. The survey consists of four sections: organizational support, psychological contract fulfillment, employee performance, and demographic information. All the items except demographic information questions were rated on a five-point Likert scale ranging from Strongly Disagree $=1$ to Strongly Agree $=5$. Perceived organizational support was measured by eight items adapted from Eisenberger, Huntington, Hutchison \& Sowa (1986, as referenced in [82]. The psychological contract is measured by two subcontracts: relational and transactional psychological contact. Both relational (6 items) and transactional (9 items) psychological contract was derived from Raja et al. (2004). Finally, the employee performance is measured by two subconstructs: in-role and extra-role performance. The extrarole performance was measured by 8 items adopted from Williams and Anderson's (1991). Further, the in-role performance measured by five items: three items were adopted from Goodman and Svyantek's (1999), and two items derived from Williams and Anderson's (1991). Information about individual attributes includes Gender, Marital status, age, work duration, income, job title, was collected as part of demographic information.

\subsection{Sample and Procedures}

All people working at a university in the Southeast US are the target population for this study. The population of the study was made up of both permanent and contract people working at the University at the time of the study (from March to June 2019). The study covered only one US-based university, conducting this study on one university would guarantee common behaviors of both managers and employees regarding the psychological contract fulfillment.

Participants' information (i.e. numbers, locations, and contact methods) was drawn from the human resources department at the University after getting IRB approval. Of the 367 distributed questionnaires, 246 were usable with a 67 percent response rate (table1).

Table 1. Sample size.

\begin{tabular}{llll}
\hline Population & Sample & Questionnaire distributed & Questionnaire collected \\
\hline 8383 & 367 & 367 & 246 \\
\hline
\end{tabular}

$$
\mathrm{n}=\frac{\mathrm{NZ}^{2} \mathrm{P}(1-\mathrm{P})}{\mathrm{Ne}^{2}+\mathrm{Z}^{2} \mathrm{P}(1-\mathrm{P})}
$$

$\mathrm{N}$ (population size in the university According to fall 2018) $=8383$ employee, e (standard error) $=.05, \mathrm{P}$ (percentage picking a choice $)=50 \%, \mathrm{Z}(95 \%$ confidence level $)=1.96$. Applying to the previous equation, $\mathrm{n}$ (sample size) $=367$ employee.

\subsection{Data Analysis}

The PLS is considered a well-established technique for estimating path coefficients in structural models [83]. For instance, PLS provides very robust model estimations with data that have normal as well as extremely non-normal distributional properties which enforce less restrictive assumptions about data normality [84]. Moreover, PLS is more suitable for small sample size, prediction, and theory development. Additionally, PLS is suitable for models that have large numbers of indicators [84]. The research hypotheses were tested using the Smart PLS-SEM version 3.2.8. A two-step process was deployed to assess the theoretical model using the software of Smart PLS-SEM version 3.2.8; the measurement model and the structural model [84].

\subsubsection{The Measurement Model (Outer Model) Quality}

The study examined both validity and reliability for all latent variables by assessing the measurement model of this study. Composite reliability (CR), which is more suitable for PLS-SEM, was used to examine the internal reliability of the constructs [84]. Moreover, the factor loadings of the indicator, composite reliability (CR), and the average variance extracted (AVE) have been considered to establish convergent validity. The discriminant validity was assessed through the square roots of AVE, Fornell \& Larcker criterion, and Heterotrait - mono trait (HTMT) ratio of correlation. Collinearity issues were also checked by the Variance Inflation Factor (VIF) for all constructs.

The CR for all latent variables (LVs) in the measurement model was greater than 0.857 and the threshold of. 7 [84].

Therefore, the results demonstrate that our measurement model had internal consistency and was reliable. All the item loadings exceed the recommended value of 0.5 , the construct CR values are greater than 0.7 and the AVE values exceed the threshold value of 0.5 [84]. Therefore, convergent validity 
was established. The full VIFs for constructs are below 5, indicating there is no multi-collinearity issue between the construct items. The discriminant values did not violate the threshold value of HTMT. 90. And all constructs correlations were lower than the square root of AVE of their respective constructs [83], therefore discriminate validity is established. All appeared to support the reliability and validity of the scales.

\subsubsection{Confirmatory Factor Analysis}

Cronbach alpha was used to test the internal consistency reliability of the instrument of measurement. The face and content validity of the instrument was conducted to ensure that the questionnaire achieved its purpose. Face validity was achieved using experts from faculty based-members from a US university independently who evaluated the adequacy and suitability of the questions in eliciting the desired responses. Their comments were incorporated to produce the final draft of the questionnaire. A questionnaire survey was used to facilitate the collection of information. The following sections further explain the different aspects of data collection and methods used to analyze collected data.

Reliability results are given in the table below. The data indicate that the measures are robust in terms of their internal consistency reliability as indexed by the composite reliability. The composite reliabilities of the different measures range from.92 to.95 which exceeds the recommended threshold value of.70. In addition consistent with the guidelines of Fornell and Larker the average variance extracted for each measure exceeded 0.50 .

All the square roots of AVEs construct are higher than the lower coefficient of transverse elements in the equivalent rows and columns; hereafter discriminant validity has been established.

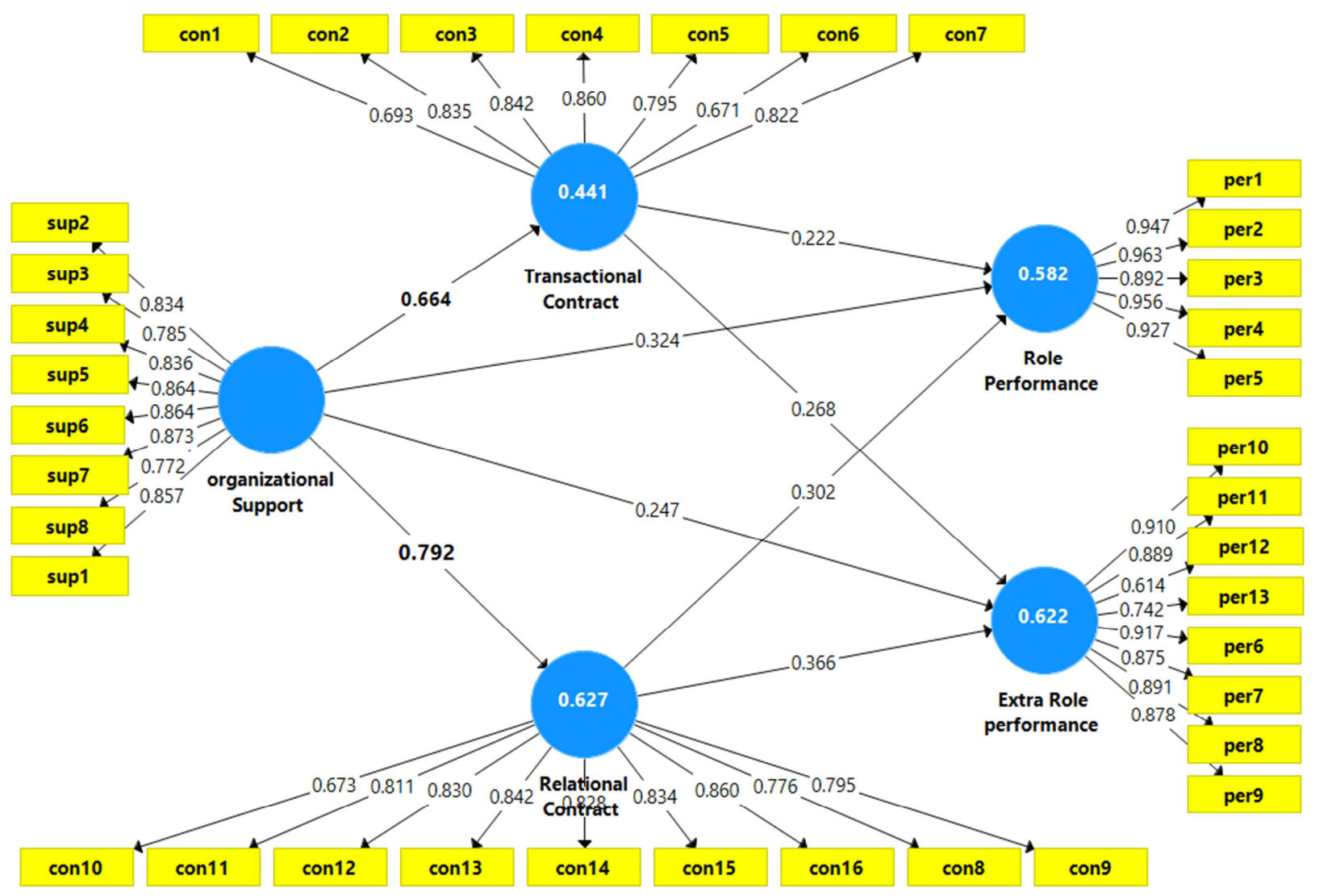

Figure 2. Research model.

Factor loadings are there to analyze the convergent validity of construct it is composite reliability and average variance extract. The validity of constructs is considered to be convergent when items load results high (0.50) on their subordinate Constructs and outcomes. Average composite reliability and variance extract are used to measure convergent validity of constructs. The AVE values of all items are above $(0.50)$. And composite reliability is higher than (0.8) representing that convergent validity of all constructs has been established.

\subsubsection{Hetero Trait - Mont Trait Ratio}

Table 3 shows the HTMT ratio it is an approach to access discriminant validity that is another effective and alternative approach to determine discriminant validity. To ensure the discriminant validity HTMT ratio should be less than 0.85 and in the case of evidence of discriminant validity all the ratio values are higher than the lower threshold. 
Table 2. Factor loadings, alpha Cronbach, average variance explained and composite reliability.

\begin{tabular}{|c|c|c|c|c|}
\hline & Loadings & Alpha Cronbach & AVE & CR \\
\hline \multicolumn{5}{|c|}{ Organizational support } \\
\hline Sup1 & 0.856 & \multirow{9}{*}{.938} & \multirow{9}{*}{.699} & \multirow{9}{*}{.948} \\
\hline Sup2 & 0.834 & & & \\
\hline Sup3 & 0.784 & & & \\
\hline Sup4 & 0.836 & & & \\
\hline Sup 5 & 0.864 & & & \\
\hline Sup6 & 0.864 & & & \\
\hline Sup7 & 0.872 & & & \\
\hline Sup8 & 0.771 & & & \\
\hline \multicolumn{2}{|c|}{ Transactional contract } & & & \\
\hline Con1 & 0.693 & \multirow{8}{*}{.899} & \multirow{7}{*}{.626} & \multirow{7}{*}{.920} \\
\hline Con2 & 0.834 & & & \\
\hline Con3 & 0.842 & & & \\
\hline Con4 & 0.859 & & & \\
\hline Con5 & 0.794 & & & \\
\hline Con6 & 0.671 & & & \\
\hline Con 7 & 0.821 & & & \\
\hline \multicolumn{4}{|c|}{ Relational contract } & \\
\hline Con8 & 0.776 & \multirow{10}{*}{.932} & \multirow{10}{*}{.651} & \multirow{10}{*}{.943} \\
\hline Con9 & 0.795 & & & \\
\hline Con10 & 0.672 & & & \\
\hline Con11 & 0.811 & & & \\
\hline Con12 & 0.829 & & & \\
\hline Con13 & 0.841 & & & \\
\hline Con14 & 0.828 & & & \\
\hline Con15 & 0.834 & & & \\
\hline Con16 & 0.860 & & & \\
\hline \multicolumn{2}{|c|}{ Role performance } & & & \\
\hline Perl & 0.946 & \multirow{6}{*}{.965} & \multirow{5}{*}{.651} & \multirow{5}{*}{.972} \\
\hline Per2 & 0.962 & & & \\
\hline Per3 & 0.891 & & & \\
\hline Per4 & 0.955 & & & \\
\hline Per5 & 0.926 & & & \\
\hline \multicolumn{4}{|c|}{ Extra role performance } & \\
\hline Per6 & 0.917 & \multirow{8}{*}{.940} & \multirow{8}{*}{.714} & \multirow{8}{*}{.951} \\
\hline Per7 & 0.874 & & & \\
\hline Per8 & 0.890 & & & \\
\hline Per9 & 0.878 & & & \\
\hline Per10 & 0.910 & & & \\
\hline Per11 & 0.889 & & & \\
\hline Per12 & 0.614 & & & \\
\hline Per13 & 0.741 & & & \\
\hline
\end{tabular}

Table 3. Hetero trait - Mont trait ratio.

\begin{tabular}{|c|c|c|c|c|c|}
\hline Construct & $\begin{array}{l}\text { organizational } \\
\text { Support }\end{array}$ & Role Performance & $\begin{array}{l}\text { Extra Role } \\
\text { performance }\end{array}$ & Transactional Contract & $\begin{array}{l}\text { Relational } \\
\text { Contract }\end{array}$ \\
\hline organizational Support & & 0.744 & 0.756 & 0.704 & 0.840 \\
\hline Role Performance & & & 0.943 & & 0.732 \\
\hline Extra Role performance & & & & & \\
\hline Transactional Contract & & 0.660 & 0.706 & & 0.681 \\
\hline Relational Contract & & & 0.769 & & \\
\hline
\end{tabular}

Table 4. Collinearity statistics of structural model (inner VIFs).

\begin{tabular}{|c|c|c|c|c|c|}
\hline Construct & $\begin{array}{l}\text { organizational } \\
\text { Support }\end{array}$ & Role Performance & $\begin{array}{l}\text { Extra Role } \\
\text { performance }\end{array}$ & Transactional Contract & $\begin{array}{l}\text { Relational } \\
\text { Contract } \\
\end{array}$ \\
\hline $\begin{array}{l}\text { Organizational Support } \\
\text { Role Performance } \\
\text { Extra Role performance }\end{array}$ & & 3.036 & 3.036 & 1.000 & 1.000 \\
\hline Transactional Contract & & 1.89 & 1.89 & & \\
\hline Relational Contract & & 2.84 & 2.84 & & \\
\hline
\end{tabular}




\subsubsection{Collinearity Statistics of Structural Model (Inner VIFs)}

Collinearity concern of the focal constructs was assessed by calculating the VIF values, which was less than five (Table4) thus concludes that collinearity was not a threat.

\section{Descriptive Analysis}

$60.2 \%$ from participants were female and $39.8 \%$ from participants were male. Of participants $52,8 \%$ were married, $41.7 \%$ were single, $3,4 \%$ were divorced and $2.1 \%$ were widow. $48.2 \%$ from participants were between 25 to 35 years old, $22.8 \%$ from participants were between 36 to 45 years old. $18 \%$ were between 46 to 55 years old. $5.3 \%$ from participants were from 56 to 60 years old. And only $5.7 \%$ were above 60 years old. Of the participants $68 \%$ were full time employment and only $32 \%$ were part time employment.76.7\% from participants were employee and $23.3 \%$ were a academic stuff. $53.6 \%$ from participant working from 1 to 3 years in the university. $14.5 \%$ working from 4 to 6 years. $14 \%$ working more than 15 years, $8.5 \%$ working from 7 to 9 years, $6.8 \%$ working from 10 to 12 years and $2.6 \%$ working from 13 to 15 years. $57 \%$ from participants have annual income less than $50.000 \$, 30.4 \$$ from participants have annual income from $50.000 \$$ to $100.000 \$, 9.6 \%$ from participants have annual income from 101.000 to $150000 \$$ and $3 \%$ from participants have annual income more than $150.000 \%$.

\section{Path Coefficients}

Path analysis was used to examine the concepts of interest as proposed in the conceptual framework. Path analysis allowed the proposed direct and indirect relationships to be tested simultaneously [75].

\subsection{Organizational Support and Psychological Contract Fulfillment}

Path coefficients analysis results show that there is a relationship between organizational support and psychological contract fulfillment constructs. The organizational support was found to be positively related to relational contract $(\beta=0.79)$ and transactional contract $(\beta=0.66)$.

\subsection{Psychological Contract Fulfillment and Employee Performance}

Path coefficients analysis results show that there is a relationship between psychological contract fulfillment and employee performance. Psychological contract fulfillment was found to be positively related to employee performance and its constructs (role performance $(\beta=.737)$ and extra role performance $(\beta=.774))$. These relationships have been theoretically supported in the literature $[1,3]$.

\subsection{Organizational Support and Employee Performance}

Path coefficients analysis results show that there is a weak relationship between organizational support and employee performance constructs. The organizational support was found to be positively weak related to role performance $(\beta=$ $0.324)$ and extra role performance $(\beta=0.246)$.

Table 5. Total direct effects.

\begin{tabular}{|c|c|c|c|c|c|}
\hline & $\begin{array}{l}\text { organizational } \\
\text { Support }\end{array}$ & $\begin{array}{l}\text { Role } \\
\text { Performance }\end{array}$ & Extra Role performance & $\begin{array}{l}\text { Transactional } \\
\text { Contract } \\
\end{array}$ & $\begin{array}{l}\text { Relational } \\
\text { Contract }\end{array}$ \\
\hline $\begin{array}{l}\text { organizational Support } \\
\text { Role Performance } \\
\text { Extra Role performance }\end{array}$ & & 0.324 & 0.246 & 0.663 & 0.791 \\
\hline Transactional Contract & & 0.222 & 0.267 & & \\
\hline Relational Contract & & 0.302 & 0.366 & & \\
\hline
\end{tabular}

Table 6. Indirect effects.

\begin{tabular}{|c|c|c|c|c|c|}
\hline & $\begin{array}{l}\text { organizational } \\
\text { Support }\end{array}$ & Role Performance & Extra Role performance & Transactional Contract & $\begin{array}{l}\text { Relational } \\
\text { Contract }\end{array}$ \\
\hline organizational Support & & 0.386 & 0.467 & & \\
\hline
\end{tabular}

Table results show that psychological contract fulfillment plays an important role as a mediator between organizational support and employee performance. Results show that the relationship between organizational support and role performance enhanced with a value of $(\beta=0.386)$ and the relationship between organizational support and extra role performance enhanced with a value of $(\beta=0.467)$.

Table 7. Total Effects.

\begin{tabular}{|c|c|c|c|c|c|}
\hline & organizational Support & Role Performance & $\begin{array}{l}\text { Extra Role } \\
\text { performance }\end{array}$ & $\begin{array}{l}\text { Transactional } \\
\text { Contract }\end{array}$ & $\begin{array}{l}\text { Relational } \\
\text { Contract }\end{array}$ \\
\hline $\begin{array}{l}\text { organizational Support } \\
\text { Role Performance }\end{array}$ & & 0.711 & 0.714 & 0.663 & 0.791 \\
\hline Extra Role performance & & & & & \\
\hline Transactional Contract & & 0.222 & 0.267 & & \\
\hline Relational Contract & & 0.302 & 0.366 & & \\
\hline
\end{tabular}




\subsection{Demographic Variables, Psychological Contract and Employee Performance}

Analysis results suggest that only gender, type of work and work period from all demographic variables had significant positive correlation with psychological contract fulfillment $(\mathrm{P}$ $=0.024, \mathrm{P}=0.037, \mathrm{p}=0.0006$ respectively). Likewise age from all demographic variable that had significant positive affect on employee performance $(\mathrm{P}=0.042)$.

\section{Discussion}

This study illustrates the role of psychological contract fulfillment play in enhancing the relationship between organizational support and employee performance. Applying on the employee working in one American university the findings of this study will be highlighted and discussed.

First, the findings revealed that organizational support had appositive effect on psychological contract fulfillment as the employer's commitment to caring for the employees may increase employees' affective commitment to the organization. Moreover, perceived organizational support may increase the employees' level of affective commitment by satisfying their social and emotional needs, such as providing affiliation and emotional support. So this will help in increasing the expectation between employer and employee. Therefore the analysis results supported the first hypotheses "There is statistically significant relationship between organizational support and psychological contract fulfillment by its dimension (contract of relations, contract of transactions) among employees in the university under study".

Second, Employees who believe they have been well supported by the organization are more likely to reciprocate by performing better at their work than those who reported lower levels of perceived organizational support [85]. As a result, perceived organizational support is positively related to employee performance consistent with previous studies [86]. So, we supported the second hypothesis" The higher fulfillment of psychological contract the better performance of employees in the university under study".

Third, our study implies that employees who perceive that their contracts are being fulfilled may increase their level of performance. Consistent with previous studies [1, 3, 73]. So the results of the analyses revealed that psychological contract play a vital role in the relationship between organizational support and employee performance. Therefore, we supported the third hypothesis" Psychological contract fulfillment mediates the relationship between organizational support and the performance of the employee. So that the organizational support will affect the psychological contract fulfillment and psychological contract fulfillment will affect the performance of the employee".

Fourth, in line with the previous studies [54] gender hadn't any effect in (organizational support, performance). Likewise, gender, type of work and work period had a positive effect in psychological contract. Besides; age hadn't any effect in (organizational support, psychological contract), but age had a positive effect on employee performance. On the contrary with [54] study age had negative effect with organizational support, psychological contract, and citizenship behavior.

So, we partially supported the fourth hypothesis" There is statistically significant relationship between Demographic variables and organizational support, psychological contract, and employee performance separately".

\section{Implications}

The implications of the study are classified in to theoretical implications and practical implications.

\subsection{Theoretical Implications}

The results suggest that psychological contract fulfillment not only covers transactional contracts but also affects the relational contracts of employees. This is an additional contribution of this study which is in line with [54].

The findings of this study support a positive role of organizational support in psychological contract. Likewise [54] study found a positive impact of psychological contract fulfillment in organizational support.

Consistent with previous studies [78], the findings of the study support a positive role of psychological contract in enhancing employee performance both in terms of in-role and extra role performance [54, 87].

\subsection{Practical Implications}

The study contributes to the debate about the different interpretation of the employer's obligations and their fulfillment among the research and education-oriented academics and staff of the university under study. Exploring the psychological contract from both employee and employer perspectives will help in understanding shared expectations [88]. More satisfied employees may also serve as brand ambassadors of the university, speaking well of it to those outside the university, promoting its image, and attracting top talent [80]. University should encourage and promote extrarole behaviors in the workplace.

Additional research should include a wide range of universities and make comparisons across national borders.

\section{Conclusion}

We examine psychological contract expectations by employees and the mediating role of psychological contract fulfillment in the relationship between organizational support and employee performance. It was deducted that there is a significant relationship between organizational support and psychological contract, and there is a significant relationship between psychological contract fulfillment and employee performance. In addition, psychological contract fulfillment plays an important role as a mediator in the relationship between organizational support and employee performance. 


\section{References}

[1] Cheng, X., \& Xu, D. (2016). Links between Psychological Contract and Job Performance of Employee in E-Business Company. Links.

[2] Suharto, S., \& Nusantoro, J. (2018). The Relationship among Managerial Capability, Organizational Citizenship Behavior, and Employee Performance: Mediation Effects of Organizational Culture. Journal of Community Research and Service, 2 (1), 168-175.

[3] Sobaih, A. E. E., Ibrahim, Y., \& Gabry, G. (2019). Unlocking the black box: Psychological contract fulfillment as a mediator between HRM practices and job performance. Tourism Management Perspectives, 30, 171-181.

[4] Soomro, S. K., \& Hafeez, M. (2020). Workplace Politics and Employee's Job Performance: Mediating Role of Job Stress, Evidence from Degree Awarding Institutions of Sindh, Pakistan. International Journal of Psychosocial Rehabilitation, 24 (04).

[5] Chahar, B. (2019). Psychological Contract and Organizational Citizenship Behavior: Exploring The Interelatedness Through Cross Validation. Academy of Strategic Management Journal, 18 (1), $1-15$.

[6] Ballou, N. S. (2013). The effects of psychological contract breach on job outcomes. Master's Theses. 4327. http://scholarworks.sjsu.edu/etd_theses/4327.

[7] Armstrong, M., \& Taylor, S. (2014). Armstrong's handbook of human resource management practice. Kogan Page Publishers.

[8] Neves, P., \& Eisenberger, R. (2014). Perceived organizational support and risk taking. Journal of managerial psychology, 29 (2), 187-205.

[9] Kurtessis, J. N., Eisenberger, R., Ford, M. T., Buffardi, L. C., Stewart, K. A., \& Adis, C. S. (2017). Perceived organizational support: A meta-analytic evaluation of organizational support theory. Journal of Management, 43 (6), 1854-1884.

[10] Paillé, P. (2015). Perceived organizational support and work outcomes: The mediating role of psychological contract violation. International Journal of Organizational Analysis, 23 (2), 191-212.

[11] Li, Z., Long, C., \& Er-Yue, T. (2018). When Does Job Insecurity Lead to Feedback-Seeking Behavior? The Counterintuitive Moderating Role of Perceived Organizational Support. Current Psychology, 37 (4), 850-861.

[12] Riggle, R. J. (2007). The impact of organizational climate variables of perceived organizational support, workplace isolation, and ethical climate on salesperson psychological and behavioral work outcomes.

[13] Hong, E., Jeong, Y., \& Downward, P. (2019). Perceived organizational support, internal motivation, and work-family conflict among soccer referees. Managing Sport and Leisure, $1-14$.

[14] Nielsen, S. K. (2006). A multi-source model of perceived organizational support and performance.

[15] Argon, T., \& Ekinci, S. (2017). Teacher Views on Organizational Support and Psychological Contract Violation.
Journal of Education and Practice, 8 (2), 44-55.

[16] Zhuang, W. (2017). The Relationship between supervisor supportive behavior and perceived organizational support: test of mediator and moderator variables (Doctoral dissertation, University at Albany. Department of Psychology).

[17] Hempfling, M. S. (2015). Happiness, Work Engagement, and Perception of Organizational Support of Student Affairs Professionals (Doctoral dissertation, Ohio University).

[18] Tongur, 2011, Organizational Support, Organizational Citizenship Behavior, and Perceived Performance: Analysis of Crime Scene Investegation Units of Turkish National Police.

[19] Du Plessis, L. (2010). The relationship between perceived talent management practices, perceived organizational support (POS), perceived supervisor support (PSS) and intention to quit amongst Generation $\mathrm{Y}$ employees in the recruitment sector (Doctoral dissertation, University of Pretoria).

[20] Mitchell, J. I., Gagné, M., Beaudry, A., \& Dyer, L. (2012). The role of perceived organizational support, distributive justice and motivation in reactions to new information technology. Computers in Human Behavior, 28 (2), 729-738.

[21] Wu, C. C., \& Liu, N. T. (2014). Perceived organizational support, organizational commitment and service-oriented organizational citizenship behaviors. International Journal of Business and Information, 9 (1), 61.

[22] Osabutey, B. E. (2018). Leadership practices, organizational support, and organizational citizenship behavior among texas nursing leaders and staff (Order No. 10837723). Available from ProQuest Dissertations \& Theses Global. (2078960502). Retrieved from https://search.proquest.com/docview/2078960502?accountid= 178282 .

[23] Adams, I., \& Mastracci, S. (2019). Police body-worn cameras: Effects on officers' burnout and perceived organizational support. Police Quarterly, 22 (1), 5-30.

[24] Qi, F., Li, R., \& Jia, Z. (2019, February). Influences of Perceived Organizational Support on the Safety Management Performance of Airline. In Journal of Physics: Conference Series (Vol. 1168, No. 3, p. 032111). IOP Publishing.

[25] Keskinkılıç Kara, Sultan Bilge \& Zafer Gunes, Demet \& Nazar Aydoğan, Nazlı. (2015). Perceived organizational support and organizational trust in primary schools. International Journal of Human Sciences. 12. 385. $10.14687 / \mathrm{v} 12 \mathrm{i} 2.3326$.

[26] Seppänen, A. M. (2012). Perceptions of Perceived Organizational Support and Affective Organizational Commitment in Radisson Blu Seaside.

[27] Chen, Y. P., \& Shaffer, M. A. (2017). The influences of perceived organizational support and motivation on selfinitiated expatriates' organizational and community embeddedness. Journal of World Business, 52 (2), 197-208.

[28] Mesimo-Ogunsanya, E. A. (2017). Organizational support and employees' work-life quality.

[29] Gokul, A., Sridevi, G., \& Srinivasan, P. T. (2012). The relationship between perceived organizational support, work engagement and affective commitment. AMET International Journal of Management, 29-37. 
[30] Miao, R. T. (2011). Perceived organizational support, job satisfaction, task performance and organizational citizenship behavior in China. Journal of Behavioral and Applied Management, 12 (2), 105.

[31] Mohamed, A., \& Ali, M. (2015). The influence of perceived organizational support on employees' job performance. International Journal of Scientific and Research Publications, 5 (4), 1-6.

[32] Nguyen, T. (2017). The perception of organizational support: Links with psychological outcomes in working students (Order No. 10685142). Available from ProQuest Dissertations \& Theses Global. (2001587696). Retrieved from https://search.proquest.com/docview/2001587696?accountid= 17828.

[33] Akgunduz, Y., \& Sanli, S. C. (2017). The effect of employee advocacy and perceived organizational support on job embeddedness and turnover intention in hotels. Journal of Hospitality and Tourism Management, 31, 118-125.

[34] Choi, Y. (2019). A study of the effect of perceived organizational support on the relationship between narcissism and job-related attitudes of Korean employees. Cogent Business \& Management, 6 (1), 1573486.

[35] Hur, W. M., Moon, T. W., \& Choi, W. H. (2019). The Role of Job Crafting and Perceived Organizational Support in the Link between Employees' CSR Perceptions and Job Performance: A Moderated Mediation Model. Current Psychology, 1-15.

[36] Palmer, J. C., Komarraju, M., Carter, M. Z., \& Karau, S. J. (2017). Angel on one shoulder: Can perceived organizational support moderate the relationship between the Dark Triad traits and counterproductive work behavior? Personality and Individual Differences, 110, 31-37.

[37] Sewpersad, R., Ruggunan, S., Adam, J. K., \& Krishna, S. B. N (2019). The Impact of the Psychological Contract on Academics. SAGE Open, 9 (2), 2158244019840122.

[38] Yan, Z., \& Mansor, Z. B. D. (2019, April). Reviews of Psychological Contract Researches. In 1st International Symposium on Education, Culture and Social Sciences (ECSS 2019). Atlantis Press.

[39] Abela, F., \& Debono, M. (2019). The Relationship between Psychological Contract Breach and Job-Related Attitudes within a Manufacturing Plant. SAGE Open, 9 (1), 2158244018822179 .

[40] Hammer, B., Zhang, T., Shadbad, F. N., \& Agrawal, R. (2019, January). Psychological Contract Violation and Sharing Intention on Facebook. In Proceedings of the 52nd Hawaii International Conference on System Sciences.

[41] Shen, Y., Schaubroeck, J. M., \& Zhao, L. (2019). Work Group Climate and Behavioral Responses to Psychological Contract Breach. Frontiers in psychology, 10, 67.

[42] Stafford, J. (2007). An Examination of the Relationship between a Realistic Job Preview and Job Applicants' Psychological Contract Perceptions (Doctoral dissertation).

[43] Malhotra, N., Sahadev, S., \& Purani, K. (2017). Psychological contract violation and customer intention to reuse online retailers: Exploring mediating and moderating mechanisms.
[44] Gallani, S., Krishnan, R., Marinich, E. J., \& Shields, M. D. (2019). Budgeting, Psychological Contracts, and Budgetary Misreporting. Management Science.

[45] Jeong, J., Kurnia, S., Samson, D., \& Cullen, S. (2018). Psychological Contract in IT Outsourcing: A Systematic Literature Review.

[46] Dhanpat, N., Nemarumane, L., Ngobeni, N. P., Nkabinde, D., \& Noko, S. (2019). Psychological contract and job security among call centre agents: Preliminary evidence. Journal of Psychology in Africa, 29 (1), 73-79.

[47] Bal, P. M., \& Vantilborgh, T. (2019). Lifespan Perspectives on Psychological Contracts. In Work across the Lifespan (pp. 455-474). Academic Press.

[48] Abdel moteleb, S. A. (2019). The interrelationships among job satisfaction, work-home interference and psychological contract breach. German Journal of Human Resource Management, 33 (1), 32-55.

[49] Sandhya, S., \& Sulphey, M. M. (2019). An assessment of contribution of employee engagement, psychological contract and psychological empowerment towards turnover intentions of IT employees. International Journal of Environment, Workplace and Employment, 5 (1), 22-31.

[50] Coyle-Shapiro, J. A. M., Pereira Costa, S., Doden, W., \& Chang, C. (2019). Psychological contracts: Past, present, and future. Annual Review of Organizational Psychology and Organizational Behavior, 6, 145-169.

[51] Chang, C. (2018). A multi-study investigation of the role of psychological needs in understanding behavioural reactions to psychological contract breach (Doctoral dissertation, The London School of Economics and Political Science (LSE)).

[52] Atkinson, T. P., Matthews, R. A., Henderson, A. A., \& Spitzmueller, C. (2018). Reactions to psychological contract breaches and organizational citizenship behaviors: An experimental manipulation of severity. Stress and Health.

[53] Memon, K. R., \& Ghani, B. (2020). The relationship between psychological contract and voice behavior - a social exchange perspective. Asian Journal of Business Ethics, 1-18.

[54] Ahmad, I., \& Zafar, M. A. (2018). Impact of psychological contract fulfillment on organizational citizenship behavior: Mediating role of perceived organizational support. International Journal of Contemporary Hospitality Management, 30 (2), 1001-1015.

[55] Mohamed, A. (2019). The effects of psychological contract fulfillment on perceived fairness of performance appraisal among working Generation Y.

[56] Oliveira, A., Moro, S., \& Torres, P. (2019). Psychological contract, internal branding and employee turnover in an IT company. Psychological contract, internal branding and employee turnover in an IT company, (1), 9-18.

[57] Li, J. J., Wong, I. A., \& Kim, W. G. (2016). Effects of psychological contract breach on attitudes and performance: The moderating role of competitive climate. International Journal of Hospitality Manasgement, 55, 1-10.

[58] Liang, H. L. (2019). Are Emotions Transmitted from Work to Family? A Crossover Model of Psychological Contract Breach Psychological reports, 122 (1), 288-304. 
[59] Kiruja, E. K., \& Mukuru, E. (2018). Effect of motivation on employee performance in public middle level Technical Training Institutions in Kenya. IJAME.

[60] Manzoor, F., Wei, L., Nurunnabi, M., Subhan, Q. A., Shah, S. I. A., \& Fallatah, S. (2019). The impact of transformational leadership on job performance and CSR as mediator in SMEs. Sustainability, 11 (2), 436.

[61] Hussain, S. D., Khaliq, A., Nisar, Q. A., Kamboh, A. Z., \& Ali, S. (2019). Impact of Employees' Recognition, Rewards and Job Stress on Job Performance: Mediating Role of Perceived Organization Support.

[62] Fathin, A., Ningrum, L., \& Abas, A. J. (2019). The Influence of Recruitment Process On Performance Of New Employees At 5 Star Hotel Jakarta. Ikra-Ith Humaniora: Jurnal Sosial dan Humaniora, 3 (2), 12-17.

[63] Krishnan, R., Loon, K. W., \& Tan, N. Z. (2018). The effects of job satisfaction and work-life balance on employee task performance. Int. J. Acad. Res. Bus. Soc. Sci, 8, 652-663.

[64] Bauer, T., Erdogan, B., and short. J. (2019), Principles of Management, version 4, Flat World, Boston.

[65] Khan, R. U., \& Ghufran, H. (2018). The Mediating Role of Perceived Organizational Support between Qualitative Job Insecurity, Organizational Citizenship Behavior and Job Performance. J Entrepren Organiz Manag, 7 (228), 2.

[66] Sonko, M. K. (2018). Leadership Strategies to Improve Employee Performance in the Insurance Industry. Doctorate dissertation, Walden University.

[67] Guo, C. (2016). Employee attributions and psychological contract breach in China (Doctoral dissertation, University of Manchester). http://dx.doi.org/10.1108/IJOA-11-20120627 .

[68] Prajogo, W. (2019). The relationship among emotional exhaustion, job satisfaction, performance, and intention to leave. Advances in Management and Applied Economics, 9 (1), 21-29.

[69] Yongxing, G., Hongfei, D., Baoguo, X., \& Lei, M. (2017). Work engagement and job performance: the moderating role of perceived organizational support. Anales de Psicología/Annals of Psychology, 33 (3), 708-713.

[70] Guan, X., \& Frenkel, S. (2018). How HR practice, work engagement and job crafting influence employee performance. Chinese Management Studies.

[71] Song, J. H., Chai, D. S., Kim, J., \& Bae, S. H. (2018). Job Performance in the Learning Organization: The Mediating Impacts of Self - Efficacy and Work Engagement. Performance Improvement Quarterly, 30 (4), 249-271.

[72] Shane, J. M. (2010). Organizational stressors and police performance. Journal of criminal justice, 38 (4), 807-818.

[73] Conway, N., \& Coyle - Shapiro, J. A. M. (2012). The reciprocal relationship between psychological contract fulfillment and employee performance and the moderating role of perceived organizational support and tenure. Journal of occupational and Organizational Psychology, 85 (2), 277-299.
[74] Bryan, T. (2014). Principles of Management, Saylor Academy.

[75] Mallette, C. (2011). Nurses' work patterns: perceived organizational support and psychological contracts. Journal of Research in Nursing, 16 (6), 518-532.

[76] Aselage, J., \& Eisenberger, R. (2003). Perceived organizational support and psychological contracts: A theoretical integration. Journal of Organizational Behavior: The International Journal of Industrial, Occupational and Organizational Psychology and Behavior, 24 (5), 491-509.

[77] Suarthana, J. H. P., \& Riana, I. G. (2016). The effect of psychological contract breach and workload on intention to leave: mediating role of job stress. Procedia-Social and behavioral sciences, 219 (31), 717-723.

[78] Turnley, W. H., Bolino, M. C., Lester, S. W., \& Bloodgood, J. M. (2003). The impact of psychological contract fulfillment on the performance of in-role and organizational citizenship behaviors. Journal of management, 29 (2), 187-206.

[79] Liao, S. H., Widowati, R., Hu, D. C., \& Tasman, L. (2017). The mediating effect of psychological contract in the relationships between paternalistic leadership and turnover intention for foreign workers in Taiwan. Asia Pacific Management Review, 22 (2), 80-87.

[80] Ahmad, I., Donia, M. B., Khan, A., \& Waris, M. (2019). Do as I say and do as I do? The mediating role of psychological contract fulfillment in the relationship between ethical leadership and employee extra-role performance. Personnel review.

[81] Karatepe, O. M., Uludag, O., Menevis, I., Hadzimehmedagic, L., \& Baddar, L. (2006). The effects of selected individual characteristics on frontline employee performance and job satisfaction. Tourism Management, 27 (4), 547-560.

[82] Chandrakar, S. (2017). Perceived organizational support and personality dimensions as predictors of job satisfaction. Indian Journal of Health and Wellbeing, 8 (1), 54.

[83] Alsetoohy, O., \& Ayoun, B. (2018). Intelligent agent technology. Journal of Hospitality and Tourism Technology.

[84] Hair, J. F., Ringle, C. M., \& Sarstedt, M. (2011). PLS-SEM: Indeed a silver bullet. Journal of Marketing theory and Practice, 19 (2), 139-152.

[85] Cheung, M. F., \& Chiu, W. C. (2005). Effects of psychological contract fulfillment, perceived organizational support, leadermember exchange, and work outcomes: A test of a mediating model. Hong Kong Polytechnic University: working paper.

[86] Chen, T., Hao, S., Ding, K., Feng, X., Li, G., \& Liang, X. (2020). The impact of organizational support on employee performance. Employee Relations: The International Journal.

[87] Hui, C., Lee, C., \& Rousseau, D. M. (2004). Psychological contract and organizational citizenship behavior in China: Investigating generalizability and instrumentality. Journal of Applied Psychology, 89 (2), 311.

[88] Shen, J. (2010). University academics' psychological contracts and their fulfillment. Journal of management development. 